\title{
SUVOKTAS SMURTO PATYRIMAS, EMOCIJŲ REGULIACIJA IR SOMATINIAI SUNKUMAI ANKSTYVOJOJE PAAUGLYSTĖJE
}

\author{
Lina Gervinskaitė-Paulaitienė $\dot{1}^{1}$ Austẻja Marija Baškyte் ${ }^{2,3}$, Neringa Čènaite் ${ }^{2}$, Lina Matutyte் $\dot{e}^{2,3}$, \\ Marija Šiaučiūnaité2 ${ }^{2}$ Rasa Barkauskiené ${ }^{1}$ \\ ${ }^{1}$ Vilniaus universiteto Filosofijos fakulteto Klinikinès ir organizacinès psichologijos katedra, \\ ${ }^{2}$ Vilniaus universiteto Medicinos fakultetas, ${ }^{3}$ Vilniaus universiteto Medicinos fakulteto \\ Psichiatrijos klinika
}

Raktažodžiai: nepalankios vaikystès patirtys, smurtas, nepriežiūra, ankstyvoji paauglystė, emocijų reguliacija, somatiniai skundai

\section{Santrauka}

Smurtas prieš vaikus yra pasaulinė visuomenès sveikatos problema, siejama su skirtingomis nepalankiomis pasekmèmis, tarp jų ir prasta emocijų reguliacija, psichosomatiniais nusiskundimais. Vis dèlto šios sąsajos ankstyvojoje paauglysteje dar per menkai suprastos. Šio tyrimo tikslas buvo ịvertinti suvokto smurto patyrimo vaikysteje ir emocijų reguliacijos bei somatinių skundų sąsajas ankstyvojoje paauglystejje. Tyrime dalyvavo 565 12-14 metų paaugliai, kurie užpildè Vaikystės patirčių klausimyną (VPK), Emocijų reguliacijos indeksą vaikams ir paaugliams (ERICA), Emocijų reguliacijos klausimyną vaikams ir paaugliams (ERQ-CA), 11-18 metu jaunuolio savęs vertinimo lapą (YSR/11-18). Šio tyrimo rezultatai atskleide, jog 23,7\% dalyvių nurodè patyrę smurtą, 7,7\% paauglių turèjo ị rizikos grupę patenkančių somatinių sunkumų. Paaugliai, kurie nurode patyrę smurtą vaikysteje, pasižymejjo prastesne emocijų reguliacija, didesniu polinkiu ị emocijų slopinimą, rečiau naudojo situacijos pervertinimą kaip emocijų reguliacijos strategiją, pasižymėjo dažnesniais somatiniais skundais nei smurto nepatyrę paaugliai. Jaunesnieji paaugliai, kurie turèjo somatinių sunkumų, taip pat pasižymejjo prastesne emocijų reguliacija. Daugiau patyrusių nei nepatyrusių smurtą paaugliu turejo labai ryškių somatinių skundų be aiškios medicininès priežasties. Suvoktas smurto patyrimas, prastesnè emocijų kontrolè, prastesnis emocijų supratimas ir rečiau naudojamas emocijų slopinimas prognozavo didesnius jaunesniųų paauglių somatinius skundus.

\section{Ivadas}

Smurtas prieš vaikus yra viena iš pagrindinių visuomenès sveikatos problemų visame pasaulyje, siejama su nepalankiomis pasekmėmis vaiko raidai ir sveikatai (1-3). Pasaulio sveikatos organizacijos duomenimis (PSO), beveik ketvirtadalis suaugusiųjų nurodo vaikystejje patyrę fizinį smurtą, 36 procentai nurodo patyrę emocinį smurtą (2). Lietuvoje smurto prieš vaikus problema taip pat aktuali: pagal vaikų mirtis dẻl patirto smurto Lietuva pirmauja tarp Europos sąjungos šalių (4). Miestų ir rajonų vaiko teisių apsaugos skyrių duomenimis, 2016 m. užfiksuotas 2681 atvejis, kada iš viso nuo smurto galimai nukentejo 2474 vaikai $(0,5 \%$ visų Lietuvoje gyvenančių vaikų) (5), tačiau gali būti, jog nemenka dalis smurto prieš vaikus atvejų yra neatpažistama ir nepatenka ị specialistų akiratị. Smurtas prieš vaiką apibrèžiamas kaip tyčinė emocinè, fizinė ar seksualinè žala arba tokios žalos grèsmè. Vaiko nepriežiūra (apleistumas) taip pat yra viena smurto rūšių, kuri apibūdinama kaip nuolatinis vaikui būtinų fizinių, emocinių ir socialinių poreikių netenkinimas ar aplaidus tenkinimas, sukeliantis žalą ar pavojų vaiko gyvybei, sveikatai, raidai (6).

Smurto patyrimas artimoje aplinkoje sutrikdo ne tik vaiko saugumo jausmą, bet gali nepalankiai veikti emocijų reguliacijos raidą (3), t. y. gebejjimą patirti ịvairias emocijas, stebèti ir vertinti emocines reakcijas, kontroliuoti (padidinti ar sumažinti) patiriamos emocijos intensyvumą ir trukmę $(7,8)$. Sèkmingam vaikų emocijų reguliacijos gebẻjimų igijimui yra itin svarbi jų patirtis artimuose santykiuose, kuriuose vaiką prižiūrintys suaugusieji užtikrina tiek fizinị, tiek emocinị saugumą, o vaikas tame santykyje su suaugusių pagalba turi galimybes mokytis pažinti ir reguliuoti savo emocijas.

Emocijų reguliacija yra sudetinis procesas, kuris gali vykti tiek sąmoningai, valingai, tiek automatiškai $(7,8)$. Ją detaliau galima apibūdinti per tris komponentus: emocijų kontrolè (pasireiškia kaip socialiai netinkamų emocinių 
išraiškų nebuvimas), emocijų supratimas (emocijų atpažinimas ir lankstumas, teigiamo afekto pastiprinimas bei neigiamo afekto silpninimas), situacinis atsakas (socialinis jautrumas ir tinkamas emocinis reagavimas socialinèse situacijose) (7). Emocijų reguliacija taip pat atsiskleidžia per reguliacijos strategijų naudojimą: pavyzdžiui, situacijos pervertinimą (situacija, galimai sukelianti emocijas, yra iš naujo įvertinama tokiu būdu, kad jos emocinis poveikis būtų mažesnis) ir emocijų slopinimą (emocinis atsakas yra susilpninamas sustabdant emocijų išraišką) (8). Žmonès, dažniau naudojantys situacijos pervertinimą, lengviau ịveikia stresą keliančius išgyvenimus ir sékmingiau pagerina savo nuotaiką, tuo tarpu emocijas slopinantys individai patiria mažiau teigiamo afekto ir mažiau sẻkmingai geba pagerinti savo nuotaiką $(8,9)$. Randasi tyrimų, rodančių, kad smurto patyrimas vaikysteje siejasi prastesniais emocijų reguliacijos gebėjimų ir neefektyvių emocijų reguliacijos strategijų naudojimu suaugystejje (10-12), tačiau mažiau žinoma apie šiuos ryšius ankstyvosios paauglystès amžiuje, kai emociniai ir kognityviniai paauglystės pokyčiai dar tik prasideda.

Skirtingi tyrimai rodo, kad prasta emocijų reguliacija vienaip ar kitaip siejasi su skirtingais psichikos sveikatos sunkumais (3). Be to, manoma, kad psichosomatiniai sunkumai gali būti susiję su prastesniu emocijų supratimu ir emocijų reguliacija (13). Karkhanis ir kolegų (2016) atliktoje apžvalgoje teigiama, kad vaikams ir paaugliams somatiniai sunkumai, kurių negalima paaiškinti medicininèmis priežastimis, dažnai atsiranda dèl sunkumų reiškiant emocijas ir jas reguliuojant (14). Tyrimuose pastebima, kad vaikai ir paaugliai, turintys stiprių somatinių skundų, turi specifinių sunkumų atpažistant, atskiriant ir analizuojant fizinius signalus, kuriuos sukelia emocinis sujaudinimas (15). Taip pat šie vaikai ir paaugliai turi sunkumų tinkamais būdais išreikšti neigiamas emocijas (16) bei dažniau ir stipriau patiria neigiamas emocijas, nei vaikai, neturintys somatinių skundų (17). Manoma, kad sunkumai atpažistant ir suprantant emocijas, kartu su stipriau patiriamomis neigiamomis emocijomis, kliudo efektyviai emocijų reguliacijai ir lemia didesnị dèmesị būtent fiziniams pojūčiams (18), o tai savo ruožtu gali būti susiję su išsakomais somatiniais nusiskundimais. Be to, autoriai kelia prielaidas, kad prastesné emocijų reguliacija taip pat gali padidinti fiziologines reakcijas emociškai sudètingose ar distresą keliančiose situacijose (18), kas irgi prisideda prie vaikų nurodomų somatinių sunkumų.

Somatiniai sunkumai gali sietis ne tik su emocijų reguliacijos problemomis, tačiau ir su patirtu vaikysteje smurtu. Tikètina, kad vaikystėje patirtas smurtas gali būti susijęs su vèlesniais psichosomatiniais skundais tiek tiesiogiai, tiek netiesiogiai per neigiamą poveikị emocijų reguliacijai, kuri, kaip jau aptarta, turi reikšmę somatinių sunkumų raiškoje.
Yra tyrimų, rodančių, kad vaikystèje patirtas smurtas gali būti susijęs su didesniais somatizacijos požymiais jauno suaugusiojo amžiuje (19). Taip pat randamos sąsajos tarp vaikysteje patirto smurto ir atskirų psichosomatinių sutrikimų, tokių kaip fibromialgija (20), funkcinè dispepsija, dirgliosios žarnos sindromas $(21,22)$, intersticinis cistitas (23) suaugusiame amžiuje. Be to, pastebėtas ryšys tarp vidurių užkietėjimo vaikystèje ir patirto fizinio, seksualinio bei emocinio smurto (24). Yra ir nedidelių studijų, atskleidžiančiu aukštesnius paaugliu, vaikystejje patyrusių smurtą, somatizacijos įverčius (25). Taigi, nors vaikystejje patirtas smurtas yra siejamas su prastesne emocijų reguliacija, somatiniais nusiskundimais, taip pat nustatoma, kad prastesnè emocijų reguliacija ir somatiniai skundai yra susiję, tačiau šių sąsajų tyrimų ankstyvojoje paauglysteje vis dar trūksta.

Darbo tikslas: išsiaiškinti sąsajas tarp suvokto smurto patyrimo, emocijų reguliacijos bei somatinių sunkumų ankstyvojoje paauglysteje.

\section{Tyrimo objektas ir metodika}

Tyrimo dalyviai. Tyrime dalyvavo 565 12-14 metų amžiaus jaunesnieji paaugliai, amžiaus vidurkis 12,56 (SD = $0,87)$. Merginos sudare $50,3 \%$, vaikinai $-49,7 \%$ tiriamujų. Didžioji dalis apklaustų jaunuolių gyveno mieste $(n=455)$, kiti - kaime ( $\mathrm{n}=109)$. Paaugliai buvo pasiekti bendradarbiaujant su skirtingomis Lietuvos mokyklomis ir kitomis ịstaigomis, dirbančiomis su vaikais.

Tyrimo instrumentai. Šiame straipsnyje pateikiamiems duomenims surinkti buvo naudoti 4 klausimynai. Suvokto smurto patyrimas vertintas Vaikystės patirčiu klausimynu (VPK, Gervinskaitė-Paulaitienè ir Barkauskienè, 2015, parengtas pagal ACE study, Felitti ir kt., 1998). VPK sudaro 10 teiginių apie 5 rūšių smurtą: emocinị smurtą, emocini apleistumą, fizini smurtą, fizini apleistumą, seksualinį smurtą (vertinimas: taip/ ne; maksimali balų suma - 10). Šiame tyrime paauglys priskirtas patyrusių smurtą grupei, jei i bent vieną klausimą atsakè teigiamai. Emocijų reguliacijai ivertinti buvo taikomi du klausimynai. Emocijų reguliacijos indeksas vaikams ir paaugliams (ERICA, MacDermott ir kt., 2010) ir Emociju reguliacijos klausimynas vaikams ir paaugliams (ERQ-CA, Gullone \& Taffe, 2011). ERICA sudare 16 klausimų, 3 subskalès, vertinančios 3 emocijų reguliavimo komponentus: Emocijų kontrolę (7 klausimai), Emocijų supratimą (5 klausimai), Situacinį atsaką (4 klausimai). Skaičiuojamas subskalių ir bendras emocijų reguliacijos įvertis (kuo aukštesnis, tuo geresnè emocijų reguliacija). ERQ-CA sudare 10 klausimų, 2 subskalès, kuriomis vertinamos emocijų reguliacijos strategijos: Situacijos pervertinimas (6 klausimai) ir Emocijų slopinimas (4 klausimai). Skaičiuojami atskirų subskalių ịverčiai, aukštesni balai 
atitinkamai rodo dažnesni situacijos pervertinimą ir dažnesnị emocijų slopinimą. Somatiniai sunkumai buvo vertinami naudojant 11-18 metų jaunuolio savęs vertinimo lapą (YSR-11/18) (Achenbach \& Rescorla, 2001). Somatiniams sunkumams ịvertinti buvo naudojama Somatinių skundų skalè, ị kurią ịtraukti klausimai apie šiuos be aiškios medicininès priežasties patiriamus nusiskundimus: košmarus, galvos svaigimą, nuovargi, skausmus, galvos skausmus, pykinimą, regos, odos problemas, virškinimo sutrikimus, vėmimą. Skaičiuotas bendras somatinių skundų skalès įvertis

1 lentelė. Emocijų reguliacija patyrusių ir nepatyrusių smurto grupėse

\begin{tabular}{|c|c|c|c|c|}
\hline & \multicolumn{2}{|c|}{ Vidutiniai rangai } & \multirow[b]{2}{*}{$\begin{array}{l}\text { Mann-Whitney } \\
\text { U kriterijus }\end{array}$} & \multirow[b]{2}{*}{$\underset{\text { reikšmė }}{\mathbf{p}}$} \\
\hline & $\begin{array}{c}\text { Nepatyre் } \\
\text { smurto }(n=379)\end{array}$ & $\begin{array}{l}\text { Patyrè smurtą } \\
(n=118)\end{array}$ & & \\
\hline Emociju kontrolè & 268,07 & 187,76 & 15134,500 & 0,000 \\
\hline Emocijų supratimas & 289,05 & 176,77 & 14272,500 & $\mathbf{0 , 0 0 0}$ \\
\hline Situacinis atsakas & 265,26 & 225,43 & 20304,000 & 0,008 \\
\hline $\begin{array}{l}\text { Bendras emocijų re- } \\
\text { guliacijos ịvertis }\end{array}$ & 266,76 & 156,12 & 11157,500 & 0,000 \\
\hline $\begin{array}{l}\text { Situacijos perverti- } \\
\text { nimas }\end{array}$ & 269,10 & 226,03 & 20578,000 & 0,005 \\
\hline Emocijų slopinimas & 249,32 & 280,59 & 21409,000 & 0,039 \\
\hline
\end{tabular}

2 lentelè. Emocijų reguliacija somatinių sunkumų normos ir rizikos grupėse

\begin{tabular}{|c|c|c|c|c|}
\hline & Vidutin & rangai & \multirow{3}{*}{$\begin{array}{l}\text { Mann-Whitney } \\
\text { U kriterijus }\end{array}$} & \multirow{3}{*}{$\underset{\text { reikšmé }}{p}$} \\
\hline & \multicolumn{2}{|c|}{$\begin{array}{l}\text { Somatinių sunkumụ } \\
\text { grupės }\end{array}$} & & \\
\hline & $\begin{array}{c}\text { Normos } \\
\text { grupé } \\
(\mathrm{n}=490)\end{array}$ & $\begin{array}{c}\text { Rizikos } \\
\text { grupé } \\
(\mathrm{n}=42)\end{array}$ & & \\
\hline Emocijų kontrolè & 249,91 & 130,83 & 4044,000 & 0,000 \\
\hline Emocijų supratimas & 261,43 & 152,95 & 4956,00 & 0,000 \\
\hline Situacinis atsakas & 250,82 & 199,93 & 6694,500 & $\mathbf{0 , 0 3 5}$ \\
\hline $\begin{array}{l}\text { Bendras emocijų reguliacijos } \\
\text { ivvertis }\end{array}$ & 242,70 & 117,38 & 3559,500 & $\mathbf{0 , 0 0 0}$ \\
\hline Situacijos pervertinimas & 253,31 & 221,14 & 7295,000 & 0,198 \\
\hline Emocijų slopinimas & 249,07 & 241,46 & 8231,000 & 0,755 \\
\hline
\end{tabular}

3 lentelè. Regresinės lygties rezultatai prognozuojant somatinių skundų ịvertị Pastaba. $* * p<0,001, * p<0,01$

\begin{tabular}{|l|c|c|c|c|c|c|c|}
\hline \multirow{2}{*}{$\begin{array}{l}\text { Progn ostiniai } \\
\text { kintamieji }\end{array}$} & \multicolumn{3}{|c|}{ 1 žingsnis } & \multicolumn{3}{|c|}{$\mathbf{2}$ žingsnis } \\
\cline { 2 - 8 } & $\boldsymbol{\beta}$ & $\mathbf{R}^{2}$ & $\mathbf{F}$ & $\boldsymbol{\beta}$ & $\mathbf{R}^{2}$ & $\begin{array}{c}\mathbf{R}^{2} \\
\text { poky- } \\
\text { tis }\end{array}$ & $\mathbf{F}$ \\
\hline Smurto patyrimas & $0,31^{* *}$ & & & $0,174^{* *}$ & & & \\
\hline Emocijų kontrole & & & & $-0,239^{* *}$ & & & \\
\hline $\begin{array}{l}\text { Emocijų suprati- } \\
\text { mas }\end{array}$ & & & $-0,293^{* *}$ & & & \\
\hline Situacinis atsakas & & 0,096 & $46,26^{* *}$ & 0,035 & 0,237 & 0,14 & $22,28^{* *}$ \\
\hline $\begin{array}{l}\text { Situacijos perver- } \\
\text { tinimas }\end{array}$ & & & & 0,062 & & & \\
\hline $\begin{array}{l}\text { Emocijų slopini- } \\
\text { mas }\end{array}$ & & & $-0,133^{*}$ & & & \\
\hline
\end{tabular}

ir, remiantis Lietuvoje sudarytomis normomis (Žukauskienè ir Kajokienè, 2007) (26), pagal Somatinių skundų skalès įverčius paaugliai priskirti vienai iš dviejų grupių: normos ir rizikos. Šiame tyrime rizikos grupei priskyrème tuos paauglius, kurių skalès ịverčiai pateko ị rizikos arba nuokrypio zonas.

Tyrimo eiga. Tyrimas buvo vykdomas mokyklose, laisvalaikio užimtumo ir dienos centruose. Tyrime dalyvavo tik tie vaikai, kurių tèvai raštu patvirtino leidimą jame dalyvauti. Anketas paaugliai pildè nedidelèse grupèse arba individualiai. Viso tyrimo metu tyrèjas būdavo kartu su tyrimo dalyviais.

Duomenų apdorojimas. Duomenys buvo analizuojami SPSS programa, taikant neparametrinius kriterijus, tiesinę hierarchinę regresiją. Skirtumas laikytas statistiškai reikšmingu, jei $\mathrm{p}<0,05$.

\section{Rezultatai}

Suvoktas smurto patyrimas. Tyrimo rezultatai rodo, kad 23,7\% jaunesniujų paauglių nurode patyrę smurtą (i bent 1 VPK klausimą atsakė teigiamai). Emocinį smurtą nurodè patyrę $12,5 \%$, fizinį smurtą $-10,3 \%$, seksualini smurtą - 1,1\%, emocinę nepriežiūrą - $13,3 \%$, fizinę nepriežiūrą $-2,5 \%$ paauglių.

Smurto patyrimas ir emocijų reguliacija. Man'o-Vitney (MannWhitney) U testas taikytas lyginant ERICA ir ERQ-CA subskaliu ịverčius tarp smurtą patyrusių ir nepatyrusių respondentų (1 lentelè). Geresne emocijų kontrole, emocijų supratimu, situaciniu atsaku pasižymejo respondentai, kurie nenurodè vaikystejje patyrę smurto. Mažesniu polinkiu naudoti situacijos pervertinimą, kaip emocijų reguliacijos strategiją, bei didesniu emocijų slopinimu pasižymėjo tie, kurie vaikystèje patyrè smurtą. 


\section{4}

Somatiniai skundai. Remiantis Jaunuolio savęs vertinimo lapo (YSR/11-18) somatinių skundų skalès įverčiais respondentai buvo suskirstyti ị dvi grupes: $92,3 \%$ paauglių priklausè normos, 7,7\% rizikos grupei.

Emocijų reguliacija ir somatiniai sunkumai. Geresne emocijų kontrole, emocijų supratimu bei situaciniu atsaku pasižymèjo jaunuoliai, kurie pateko ị somatinių sunkumų normos grupę nei tie, kurie turejjo somatinių skundų. Naudojamos emocijų reguliacijos strategijos tarp somatinių skundų grupių reikšmingai nesiskyrè (2 lentelè).

Vaikystėje patirto smurto ir somatinių skundų ryšys. Norint įvertinti vaikysteje patirto smurto ryšį su somatiniais sunkumais, smurtą patyrę ir nepatyrę tyrimo dalyviai buvo palyginti pagal patekimą i somatinių skundų normos ir rizikos grupès. Taikant Pirson'o (Pearson) chi kvardrato testą gautas rezultatas: $\chi^{2}(1)=6,397, p=0,011$ parodo, jog reikšmingai daugiau patyrusių (13,1\%), nei nepatyrusių $(6,2 \%)$ smurto respondentų priklausé somatinių skundų rizikos grupei.

Patirto smurto, emocijų reguliacijos ir somatinių skundų ryšys. Siekiant ịvertinti, kaip patirtas smurtas ir emocijų reguliacija siejasi su somatinių skundų išreikštumu, atlikta hierarchinè regresija. Pirmame žingsnyje tikrinta, ar vien tik smurto patyrimas prognozuoja somatinių skundų ịverti, o antrame žingsnyje įtraukta ir emocijų reguliacija. Gauta, kad vien smurto patyrimas reikšmingai prognozuoja somatinius skundus (modelis paaiškina beveik $10 \%$ somatinių skundų duomenų sklaidos), tačiau įtraukus emocijų reguliaciją modelis paaiškina beveik $24 \%$ somatinių skundų duomenų sklaidos ir šis padidejimas yra reikšmingas $\left(\mathrm{R}^{2}\right.$ pokytis $=0,14, \mathrm{~F}$ pokytis $=22,28, p<0,001)$. Matome, kad smurto patyrimas, prastesnè emocijų kontrolè, prastesnis emocijų supratimas ir mažesnis emocijų slopinimas reikšmingai prognozuoja somatinius skundus, o situacinis atsakas ir situacijos pervertinimo strategija nèra reikšmingi prognostiniai kintamieji (3 lentelè).

\section{Rezultatų aptarimas}

Šio tyrimo tikslas buvo atskleisti, kaip siejasi suvoktas smurto vaikysteje patyrimas, emocijų reguliacija ir somatiniai nusiskundimai ankstyvojoje paauglysteje.

Visų pirma, mūsų tyrimo rezultatai atskleidè, kad beveik ketvirtadalis jaunesniujjų paauglių nurodè, kad yra patyrę smurtą vaikystejje, dažniausios iš smurto rūšių buvo emocinis smurtas ir emocinè nepriežiūra. Šie rezultatai panašūs su PSO nurodomu retrospektyviai suaugusiujų nurodomu smurto patyrimo vaikysteje paplitimu (2).

Lyginant emocijų reguliaciją tarp jaunesniųų paauglių, kurie nurode ir nenurode patyrę smurto, rezultatai atskleidé, kad geresne emocijų reguliacija ir adaptyvesnemmis emocijų reguliacijos strategijomis pasižymėjo jaunuoliai, kurie nu- rodė vaikystejje smurto nepatyrę. Vadinasi, paaugliai, nurodantys, kad yra patyrę smurtą, sunkiau kontroliuoja emocijas ir rečiau pasirenka tinkamą reagavimą atsižvelgdami ị supantị socialinị kontekstą. Šiems paaugliams taip pat sunkiau iš naujo pervertinti emocijas keliančią situaciją taip, kad ji keltų mažiau nemalonių išgyvenimų. Patyrusiems smurtą paaugliams taip pat buvo būdingas stipriau išryškèjęs emocijų raiškos slopinimas, polinkis patiriamų emocijų nereikšti išorèje. Tyrimo rezultatai darniai papildo retrospektyvinius suaugusiųų tyrimų duomenis, kur randama, kad vaikysteje smurtą patyrę suaugę labiau linkę į emocijų disreguliaciją (10), pasižymi kitais emocijų reguliacijos sunkumais (27). Taigi matome, kad panašias sąsajas galime fiksuoti ir ankstyvoje paauglysteje.

Mūsų tyrimo duomenimis, paaugliai, turintys labai ryškių somatinių sunkumų be aiškios medicininès priežasties, pasižymejjo prastesne emocijų reguliacija. Tai atsispindi ir kituose tyrimuose, kur randama, kad emocijų reguliacijos problemos yra dažnesnès vaikams ir paaugliams, kurie turi somatinių sunkumų $(16,17,28)$. İdomu, kad mūsų tyrime somatinių sunkumų turintys paaugliai nurodè prasčiau kontroliuojantys savo emocijas, rečiau pasirenkantys socialinę situaciją atitinkantį emocinį atsaką, mažiau emociškai lanksčiai reaguojantys, tačiau jų emocijų reguliacijos strategijos nesiskyrè nuo paauglių, neturinčių daug somatinių sunkumų. Abiejų grupių paaugliai vienodai dažnai reguliuodami emocijas tiek ir adaptyviai pervertina situaciją, tiek ir slopina emocijų raišką.

Somatinių skundų rizikos grupei šiame tyrime dažniau priklause jaunuoliai, kurie nurodė patyrę smurtą. Panašios tendencijos atsiskleidžia ir kituose tyrimuose, kur ịvairiu psichosomatinių sutrikimų pasireiškimas susijęs su vaikystėje patirtu smurtu (24), randama, kad pacientai, patyrę smurtą, išsako daugiau dirgliosios žarnos sindromo simptomų (29) ir, kad emocinè nepriežiūra/smurtas dažnesni ir tarp funkcinėmis neurologinėmis ligomis sergančiujų asmenų (30).

Analizuojant, kaip somatinių sunkumų išreikštumą prognozuoja vaikysteje patirtas smurtas ir emocijų reguliacija, gavome, kad smurto patyrimas kartu su prastesne emociju kontrole, prastesniu emocijų supratimu ir mažesniu emocijų slopinimu geriau nei vien tik smurto patyrimas prognozuoja didesnius somatinius skundus. Tai rodo, kad somatinių problemų išreikštumui ankstyvojoje paauglystejje svarbus tiek smurto patyrimas, tiek dalis emocijų reguliacijos kompetencijų. Mūsų rezultatai papildo kitais raidos etapais atliktus tyrimus, kuriuose randama, kad smurto patyrimas kartu su prastesniu emocijų supratimu siejasi su somatiniais nusiskundimais suaugusiojo amžiuje (19), patirtas smurtas prognozuoja tiek emocijų reguliacijos sunkumus, tiek internalius sunkumus (i juos įtraukiant ir somatinius skundus) vidurinėje 
vaikysteje (27). Svarbu atkreipti dèmesị ị emocijų slopinimo ryšį su somatiniais skundais. Didelis emocijų slopinimas yra laikomas neefektyvia emocijų reguliacijos strategija ir galètume tikètis, kad jis siesis su didesniais somatiniais skundais. Vis dèlto mūsų tyrimo rezultatai rodo, kad mažesnis emocijų raiškos slopinimas siejosi su didesniais somatiniais nusiskundimais, o tai yra ịdomus ir tolesnių tyrimų reikalaujantis rezultatas. Iš tyrimų rezultatų taip pat matome, kad tendencija rinktis socialinę situaciją atitinkantị emocinị atsaką ir polinkis reguliuoti emocijas iš naujo pervertinant situaciją nèra reikšmingi prognozuojant somatinių sunkumų lygị.

Taigi, patirtas smurtas siejasi ne tik su emocijų reguliacijos sunkumais, bet ir žymiais somatiniais nusiskundimais, o patirtas smurtas bei prastesnè emocijų kontrole ir supratimas reikšmingai prognozuoja didesnius somatinius nusiskundimus. Šie rezultatai pateikia pradinių nuorodų ir praktiniam skirtingų sričių specialistų darbui. Šeimos gydytojams bei gydytojams pediatrams rekomenduojama vaikus ir paauglius, kurie turi somatinių sunkumų, tirti ne tik dèl fiziologinių sutrikimų, bet atkreipti dèmesị ir ị jų emocinę būklę ir, neradus jokių organinių priežasčių, nukreipti juos psichologinès pagalbos (14). Somatinès problemos susijusios su prastesne gyvenimo kokybe bei trikdo normalų asmens funkcionavimą (31), dèl to svarbu atkreipti dèmesị ir ị somatinių sunkumų prevenciją, kuriai nuorodų taip pat pateikia tyrimo rezultatai. Matome, kad somatinių sunkumų prevencijai gali būti svarbu apgalvoti ir smurto prieš vaikus prevenciją, ir psichosocialines intervencijas, skirtas emocijų reguliacijai gerinti. Skirtingo smurto patyrimą nurodančių jaunesniujų paauglių skaičius yra ženklus, kas rodo šios problemos ir jos neigiamų pasekmių aktualumą, o tai savo ruožtu prisideda prie smurto prieš vaikus prevencijos ir nepavėluotos intervencijos svarbos pagrindimo. Tai gali būti aktualu ir gydytojų, visuomenès sveikatos specialistų, socialinių darbuotojų, psichologų bei kitų susijusių profesijų atstovams.

Aptariant tyrimo ribotumus, svarbu atkreipti dèmesị, kad tyrime vertintas tik pačių paauglių nurodomas suvoktas smurto patyrimas. Gali būti, kad dalis paauglių, kurie ir yra patyrę smurtą vaikysteje, tos patirties nenorejo nurodyti ar jos nepriskyré prie smurtinès. Be to, somatiniai nusiskundimai ir emocijų reguliacija taip pat buvo vertinti pačių paauglių, kas galejjo šiek tiek paveikti tyrimo rezultatus. Dèl to tolesniuose tyrimuose būtų svarbu ieškoti būdų pasitelkti ir kitus informacijos šaltinius (tèvus, su paaugliais dirbančius specialistus, skirtingus emocijų reguliacijos vertinimo būdus ir pan.). Šiame tyrime nevertinome paaugliu emocinių sunkumų, o yra žinoma, kad tiek depresijos, tiek nerimo sutrikimams gali būti būdingi psichosomatiniai nusiskundimai, dèl to kituose tyrimuose būtų svarbu įtraukti ir emocinių sutrikimų simptomų vertinimą. Nepaisant aptartų ribotumų, tyrimo rezultatai prisideda prie geresnio patirto smurto, emocijų reguliacijos ir somatinių skundų sąsajų supratimo ankstyvojoje paauglysteje, kartu pateikdami nuorodų tolesniems tyrimams ir praktiniam darbui.

\section{Išvados}

1. Beveik ketvirtadalis tyrime dalyvavusių paauglių nurodè patyrę smurtą vaikysteje, daugiausia emocinį smurtą ir emocini apleistumą.

2. Geresne emocijų kontrole, emocijų supratimu, situaciniu atsaku bei situacijos pervertinimu pasižymėjo tie jaunuoliai, kurie vaikysteje smurto nepatyre, o didesnis emocinis slopinimas būdingesnis smurtą patyrusiems paaugliams.

3. Paaugliai, kurie nurode turintys labai ryškių somatinių skundų be aiškios medicininès priežasties, pasižymėjo blogesne emocijų kontrole ir supratimu bei situaciniu atsaku. Taip pat daugiau šių paauglių nurodè patyrę smurtą vaikysteje.

4. Suvoktas smurto patyrimas, prastesnè emocijų kontrolè, prastesnis emocijų supratimas ir mažiau naudojamas emocijų slopinimas prognozuoja didesnius jaunesniujų paauglių somatinius skundus.

\section{Literatūra}

1. Afifi TO, MacMillan HL, Boyle M, Taillieu T, Cheung K, Sareen J. Child abuse and mental disorders in Canada. CMAJ Can Med Assoc J 2014;186(9):E324-32.

https://doi.org/10.1503/cmaj.131792

2. WHO | Global status report on violence prevention. WHO. 2014. Adresas: http://www.who.int/violence_injury_prevention/violence/status_report/2014/en/

3. Dvir Y, Ford JD, Hill M, Frazier JA. Childhood maltreatment, emotional dysregulation, and psychiatric comorbidities. Harv Rev Psychiatry 2014;22(3):149-61.

https://doi.org/10.1097/HRP.0000000000000014

4. Dimitrova-Stull A. Violence towards children in EU: current situation. European Parliamentary Research Service [Prieiga per internetą]. 2014 [žiūrèta 2017 m. balandžio 27 d.]. Adresas: www.europarl.europa.eu/RegData/etudes/IDAN/2014/542139/ EPRS_IDA(2014)542139_EN.pdf

5. Smurtą patyrusių vaikų ir smurto prieš vaikus atvejų statistika. Valstybės vaiko teisių apsaugos ir ịvaikinimo tarnyba [Prieiga per internetą]. 2016 [žiūrèta 2017 m. balandžio 29 d.]Adresas: www.vaikoteises.lt/media/file/Statisitika/smurtas2016.docx. pdf

6. Vaiko teisių apsaugos pagrindų įstatymo Nr. I-1234 pakeitimo ịstatymo projektas (nauja redakcija) [Prieiga per internetą]. 2017 [žiūrèta 2017 m. gegužès 20 d.]. Adresas: https://e-seimas. lrs.1t/portal/legalAct/lt/TAP/30156e00eede11e6be918a531b21 $26 \mathrm{ab}$

7. MacDermott ST, Gullone E, Allen JS, King NJ, Tonge B. 
The emotion regulation index for children and adolescents (ERICA): a psychometric investigation. J Psychopathol Behav Assess 2010;32(3):301-14.

https://doi.org/10.1007/s10862-009-9154-0

8. Gullone E, Taffe J. The emotion regulation questionnaire for children and adolescents (ERQ-CA): a psychometric evaluation. Psychol Assess 2012;24(2):409-17. https://doi.org/10.1037/a0025777

9. John OP, Gross JJ. Healthy and unhealthy emotion regulation: personality processes, individual differences, and life span development. J Pers 2004;72(6):1301-34. https://doi.org/10.1111/j.1467-6494.2004.00298.x

10. Thompson KL, Hannan SM, Miron LR. Fight, flight, and freeze: Threat sensitivity and emotion dysregulation in survivors of chronic childhood maltreatment. Personal Individ Differ 2014;69:28-32.

https://doi.org/10.1016/j.paid.2014.05.005

11. Briere J, Jordan CE. Childhood maltreatment, intervening variables, and adult psychological difficulties in women: an overview. Trauma Violence Abuse 2009;10(4):375-88.

https://doi.org/10.1177/1524838009339757

12. Spasojević J, Alloy LB. Who becomes a depressive ruminator? Developmental antecedents of ruminative response style. J Cogn Psychother 2002;16(4):405-19.

https://doi.org/10.1891/088983902780935713

13. Taylor GJ. Affects, trauma, and mechanisms of symptom formation: a tribute to John C. Nemiah, MD (1918-2009). Psychother Psychosom 2010;79(6):339-49. https://doi.org/10.1159/000320119

14. Karkhanis DG, Winsler A. Somatization in children and adolescents: practical implications. J Indian Assoc Child Adolesc Ment Health 2016;12(1):79-115.

15. Terwogt MM, Rieffe CJ, Miers AC, Jellesma FC, Tolland A. Emotions and self-esteem as indicators of somatic complaints in children. Infant Child Dev 2006;15:581-92.

https://doi.org/10.1002/icd.479

16. Rieffe C, Terwogt MM, Bosch JD, Kneepkens CMF, Douwes $\mathrm{AC}$, Jellesma FC. Interaction between emotions and somatic complaints in children who did or did not seek medical care. Cogn Emot 2007;21(8):1630-46.

https://doi.org/10.1080/02699930701238495

17. Jellesma FC, Rieffe C, Terwogt MM, Kneepkens CMF. Somatic complaints and health care use in children: mood, emotion awareness and sense of coherence. Soc Sci Med 1982. 2006;63(10):2640-8.

https://doi.org/10.1016/j.socscimed.2006.07.004

18. Gilleland J, Suveg C, Jacob ML, Thomassin K. Understanding the medically unexplained: emotional and familial influences on children's somatic functioning. Child Care Health Dev 2009;35(3):383-90.

https://doi.org/10.1111/j.1365-2214.2009.00950.x
19. Smith AM, Flannery-Schroeder EC. Childhood emotional maltreatment and somatic complaints: the mediating role of alexithymia. J Child Adolesc Trauma 2013;6(3):157-72. https://doi.org/10.1080/19361521.2013.811456

20. Häuser W, Hoffmann E-M, Wolfe F, Worthing AB, Stahl N, Rothenberg R. et al. Self-reported childhood maltreatment, lifelong traumatic events and mental disorders in fibromyalgia syndrome: a comparison of US and German outpatients. Clin Exp Rheumatol 2015;33(1 Suppl 88):S86-92.

21. Koloski NA, Talley NJ, Boyce PM. A history of abuse in community subjects with irritable bowel syndrome and functional dyspepsia: the role of other psychosocial variables. Digestion 2005;72(2-3):86-96. https://doi.org/10.1159/000087722

22. Talley NJ, Fett SL, Zinsmeister AR. Self-reported abuse and gastrointestinal disease in outpatients: association with irritable bowel type symptoms. Am J Gastroenterol 1995;90(3):366-71.

23. Chiu C-D, Lee M-H, Chen W-C, Ho HL, Wu H-C. Childhood trauma perpetrated by close others, psychiatric dysfunction, and urological symptoms in patients with interstitial cystitis/ bladder pain syndrome. J Psychosom Res 2017;93:90-5. https://doi.org/10.1016/j.jpsychores.2016.12.014

24. Rajindrajith S, Devanarayana NM, Lakmini C, Subasinghe V, de Silva DGH, Benninga MA. Association between child maltreatment and constipation: a school-based survey using Rome III criteria. J Pediatr Gastroenterol Nutr 2014;58(4):486-90. https://doi.org/10.1097/MPG.0000000000000249

25. Atlas JA, Wolfson MA, Lipschitz DS. Dissociation and somatization in adolescent inpatients with and without history of abuse. Psychol Rep 1995;76(3c):1101-2.

https://doi.org/10.2466/pr0.1995.76.3c.1101

26. Žukauskienė R, Kajokienė I. CBCL, TRF IR YSR metodikų standartizavimas naudojant 6-18 metų Lietuvos vaikų imties duomenis. Psichologija [Prieiga per internetą]. 2006 [žiūrèta 2017 m. gegužès 24 d.];33 Adresas: http://www.zurnalai.vu.lt/ psichologija/article/view/4318

27. Kim-Spoon J, Cicchetti D, Rogosch FA. A longitudinal study of emotion regulation, emotion lability-negativity, and internalizing symptomatology in maltreated and nonmaltreated children. Child Dev 2013;84(2):512-27.

https://doi.org/10.1111/j.1467-8624.2012.01857.x

28. Rieffe C, Meerum Terwogt M, Kotronopoulou K. Awareness of single and multiple emotions in high-functioning children with autism. J Autism Dev Disord 2007;37(3):455-65.

https://doi.org/10.1007/s10803-006-0171-5

29. Drossman DA. Abuse, Trauma, and GI Illness: Is There a Link? Am J Gastroenterol 2011;106(1):14-25.

https://doi.org/10.1038/ajg.2010.453

30. Steffen A, Fiess J, Schmidt R, Rockstroh B. "That pulled the rug out from under my feet!" - adverse experiences and altered emotion processing in patients with functional neurological symptoms compared to healthy comparison subjects. BMC 
Psychiatry [Prieiga per internetą]. 2015 [žiūrèta 2017 m. gegužès 29 d.];15. Adresas: http://www.ncbi.nlm.nih.gov/pmc/ articles/PMC4477601/

31. Zonneveld LN, Sprangers MA, Kooiman CG, van 't Spijker A, Busschbach JJ. Patients with unexplained physical symptoms have poorer quality of life and higher costs than other patient groups: a cross-sectional study on burden. BMC Health Serv Res 2013;13:520.

https://doi.org/10.1186/1472-6963-13-520

\section{PERCEIVED ABUSE EXPERIENCE, EMOTION REGULATION AND SOMATIC COMPLAINTS IN EARLY ADOLESCENCE}

L. Gervinskaitè-Paulaitienè, A. M. Baškytè, N. Čènaitė, L. Matutytė, M. Šiaučiūnaitė, R. Barkauskienè

Key words: adverse childhood experiences, violence, neglect, early adolescence, emotion regulation, somatic complaints

Summary

Child abuse and neglect is a global public health problem that is linked with various negative consequences such as poor emotional regulation, psychosomatic complaints. However, understanding of these links during early adolescence is incomplete. The goal of this research was to evaluate the association between adverse childhood experiences, emotional regulation and somatic com- plaints during early adolescence. $56511-14$ years old adolescents participated in the study and completed the Childhood Experiences Questionnaire, the Emotional Regulation Questionnaire (ERICA), the Emotion Regulation Questionnaire for Children and Adolescents (ERQ-CA) and the Youth Self-Report (YSR/11-18). The data from this research showed that $23,7 \%$ of the participants reported having experienced violence in childhood, $7,7 \%$ had somatic complaints attributed to a risk group. Adolescents who reported adverse childhood experiences were characterized by weaker emotional regulation, rarer use of cognitive reappraisal strategy, tendency to use expressive suppression and more frequent somatic complaints. Young adolescents who had significant somatic difficulties also showed worse emotional regulation. The child abuse sufferers expressed more somatic complaints without any defined medical condition than non-sufferers. Perceived childhood abuse, worse emotional control, emotion understanding and rarer use of expressive suppression predicted more somatic complaints in young adolescents.

Correspondence to: lina.gervinskaite@fsf.vu.lt

Gauta 2017-06-04

\section{KVIEČIAME PRENUMERUOTI "SVEIKATOS MOKSLŲ" ŽURNALĄ 2017 METAIS!}

Žurnalas "Sveikatos mokslai" (Index Copernicus, EBSCO host (Academic Search Complete), Gale (Academic OneFile), ProQuest (Ulrich's, Summon), Australia (ERA) 2012 Journal List (ERA ID 34962) skirtas visų specialybiu gydytojams, slaugytojams ir kitiems specialistams, spausdina mokslinius straipsnius lietuvių, anglų kalbomis. Reikalavimai straipsniams atitinka mokslo leidiniams keliamus reikalavimus.

Žurnalas kioskuose neparduodamas.

Žurnalą, kuris leidžiamas kartą per du mėnesius, galima užsiprenumeruoti visuose Lietuvos pašto skyriuose, taip pat internetu: www.prenumeruok.lt

Prenumeratos kaina nesikeičia: visiems metams - 34,75 EUR, šešiems mėnesiams - 17,37 EUR, keturiems mėnesiams - 11,58 EUR, dviem mėnesiams - 5,79 EUR.

Prenumeratos kodas: 5348.

Žurnalo autoriams straipsnių spausdinimas mokamas.

Redakcija 